\title{
Genetic Divergence Studies in Pigeonpea [Cajanus cajan (L.) Millsp.]
}

\author{
Praveen Pandey $^{1 *}$, Rajesh Kumar ${ }^{1}$, Vankat Raman Pandey ${ }^{1}$, Mritunjay Tripathi ${ }^{2}$ \\ ${ }^{1}$ Department of Genetics and Plant Breeding, Narendra Deva University of Agriculture and Technology, Kumarganj, India; \\ ${ }^{2}$ Department of Biochemistry, Narendra Deva University of Agriculture and Technology, Kumarganj, India. \\ Email: "pandeypraveen1986@yahoo.com
}

Received September $4^{\text {th }}, 2013$; revised October $4^{\text {th }}, 2013$; accepted October $21^{\text {st }}, 2013$

Copyright (c) 2013 Praveen Pandey et al. This is an open access article distributed under the Creative Commons Attribution License, which permits unrestricted use, distribution, and reproduction in any medium, provided the original work is properly cited.

\begin{abstract}
The nature and extent of genetic diversity were assessed among 23 parents of pigeonpea hybrids employing Mahalanobis $\mathrm{D}^{2}$ statistics. Based on relative magnitude of $\mathrm{D}^{2}$, the genotypes were grouped into five different non-overlapping clusters. Cluster III, having 8 genotypes, emerged with highest number of entries; cluster I, II and V were constituted by four genotypes each while cluster IV, comprising three genotypes, had least number of entries. The highest contribution in manifestation of genetic divergence was exhibited by 100 -seed weight followed by pods per plant, days to maturity, harvest index, biological yield per plant, days to 50\% flowering and seed yield per plant. The maximum intra-cluster distance was observed for cluster III, followed by cluster IV, cluster I and cluster V. The highest inter-cluster distance was recorded between cluster II and IV followed by cluster I and IV and cluster V and II. The crossing between entries belonging to cluster pairs having large inter-cluster distance and possessing high cluster means for one or other characters to be improved may be recommended for isolating desirable recombinants in the segregating generations in pigeonpea. Considering the mean performance for different characters of genotypes belonging to diverse clusters, the promising genotypes identified were NDA 2, NDA 7-11, IPA 208 and NDA 5-14 of cluster I; NDA 3-3, NDA 98-6, Amar and NDACMS 1-3A of cluster II; NDACMS 1-4A, NDACMS 1-6A and ICP 870 of cluster IV and NDA 96-6, ICP 2155, NDA 8-6 and NDAGC 1010 of cluster V for exploitation as parents in hybridization programme for development of superior pigeonpea hybrid cultivars.
\end{abstract}

Keywords: Pigeonpea; Genetic Diversity; Clustering Pattern; Polygenic Traits

\section{Introduction}

Pigeonpea [Cajanus cajan (L.) Millsp.] is the second most important pulse crop of India after chickpea, commonly known as Arhar, Red gram and Tur. It has been recognized as a good source of vegetarian protein particularly in the developing countries where majority of the population depends on the low priced vegetarian foods. In fact, this crop has diversified uses such as food, feed, fodder and fuel. It is a rich source of protein, carbohydrate, vitamins, lipids and certain minerals. Compared to other food legumes, breeding in pigeonpea has been more challenging due to various crop specific traits and highly sensitive nature to biotic and abiotic stresses. The final target of any plant breeding programme is to develop improved genotypes which are better than the

\footnotetext{
"Corresponding author.
}

existing ones in producing the economic yield. This requires genetic amelioration through maximum utilization of allelic resources to develop ideal genotype.

The information about the nature and magnitude of genetic diversity existing in the available germplasm of a particular crop is crucial for selection of diverse parents, which upon hybridization may provide a wide spectrum of gene recombinations for quantitatively inherited traits. Darwin used the expression of divergence in characters to denote variation in genera, species and varieties [1]. Genetically diverse parents are preferred for use in hybridization programme because crosses involving divergent parents have been found to provide greater possibility for obtaining desirable segregants in segregating generations. The importance of genetic diversity for selecting parents for recombination breeding in crops including pigeonpea to recover transgressive segregants has also 
been repeatedly emphasized [2-6]. Earlier workers considered distances in place of origin as index of genetic diversity and used it for selection of parents for hybridization programme. However, the genetic diversity of the selected parents has not been always found to be based on factors such as geographic diversity/place of release or ploidy level $[7,8]$. Hence, characterization of genetic divergence for selection of suitable and diverse genotypes should be based on sound statistical procedures, such as $\mathrm{D}^{2}$ cluster analysis. Keeping in view, an experiment was taken up to study genetic diversity for selecting the diverse parents for hybridization programme aimed at isolating desirable segregants for seed yield and other important characters in pigeonpea.

\section{Materials and Methods}

\subsection{Experimental Detail}

Twenty three pigeonpea parental materials of hybrids (3 cytoplasmic male sterile lines and 20 restorers/maintainers genotypes) were evaluated in a randomized block design with three replications at Research Farm of Genetics and Plant Breeding, Narendra Deva University of Agriculture \& Technology, Kumarganj, Faizabad during Kharif season of 2012. The experimental site is located at $26.47^{\circ} \mathrm{N}$ latitude, $82.12^{\circ} \mathrm{E}$ longitudes and an altitude of $113 \mathrm{~m}$ above mean sea level. This site is in the eastern Gangetic plains of India and has sandy loam soil texture. Each genotype was raised in single row plots of $4 \mathrm{~m}$ length with intra-row and inter-row spacing of $25 \mathrm{~cm}$ and $75 \mathrm{~cm}$, respectively. The recommended agronomic practices followed to raise good crop stand.

\subsection{Data Collection}

The observations were recorded on five randomly selected competitive plants of a genotype for eleven characters viz., days to $50 \%$ flowering, days to maturity, number of primary branches per plant, number of secondary branches per plant, plant height $(\mathrm{cm})$, pods per plant, seeds per pod, 100-seed weight, seed yield per plant (g), biological yield per plant (g) and harvest index (\%).

\subsection{Statistical Analysis}

The mean data on eleven quantitative characters from the experiment were utilized for analysis of variance to test the significance for each character as per methodology advocated by [9]. Genetic diversity was estimated by [10] and the grouping of the genotypes into different clusters were done by using the procedure of [11].

\section{Results and Discussion}

The Mahalanobis $\mathrm{D}^{2}$ cluster analysis grouped all the 23 pigeonpea genotypes of the present investigation into five distinct non-overlapping clusters (Table 1 and Figure 1). The discrimination of genotypes into discrete clusters suggested presence of high degree of genetic diversity in the material evaluated. Earlier workers have also reported substantial genetic divergence in the pigeonpea materials [4-6,12,13]. Presence of substantial genetic diversity among the parental material screened in the present study indicated that this material may serve as good source for selecting the diverse parents for hybridization programme aimed at isolating desirable segregants for seed yield and other important characters.

An examination of the clustering pattern of the 23 pigeonpea genotypes into five clusters revealed that the genotypes of heterogeneous origin were frequently present in same cluster. Although the genotypes originated in same place or geographic region were also found to be grouped together in same cluster, the instances of grouping of genotypes of different origin or geographical regions in same cluster were observed in case of all the clusters. This indicated lack of any definite relationship or correlation between genetic diversity and geographic origin of the pigeonpea genotypes evaluated in the present study. Therefore, the selection of parental material for hybridization programme simply based on geographic diversity may not be rewarding exercise. The choice of suitable diverse parents based on genetic divergence analysis would be more fruitful than the choice made on the basis of geographical distances. This finding is in conformity with the previous reports advocating lack of parallelism between genetic and geographic diversity in

Table 1. Distribution of parents into different clusters on the basis of Mahalanobis $\mathrm{D}^{2}$ statistics.

\begin{tabular}{lcc}
\hline Clusters & Name of genotypes included & No. of genotypes included \\
\hline 1 Cluster & NDA 2, NDA 7-11, IPA 208, NDA 5-14 & 4 \\
2 Cluster & NDA 3-3, NDA 98-6, Amar, NDACMS 1-3A & 4 \\
3 Cluster & NDA 3, ICP 7353, NDA 96-1, ICP 2309, NDAGC 31, NDA 7-15, Bahar, NDA 98-7 & 8 \\
4 Cluster & NDACMS1-4A, ICP 870 NDACMS 1-6A & 3 \\
5 Cluster & NDA 96-6, ICP 2155, NDA 8-6, NDAGC 1010 & 4 \\
\hline
\end{tabular}




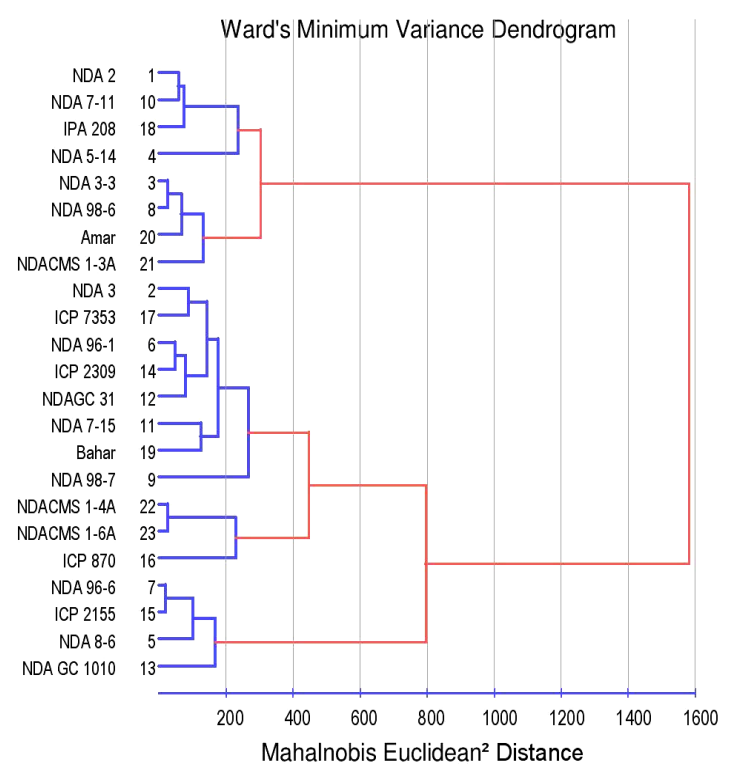

Figure 1. Ward's minimum variance dendrogram.

pigeonpea [12-14].

Cluster III, having 8 genotypes, emerged with highest number of entries. Cluster I, II and V were constituted by four genotypes each while Cluster IV, comprising three genotypes, had least number of entries.

The estimates of average intra- and inter-cluster distances for five clusters (Table 2, Figure 2) revealed that the genotypes present in a cluster have little genetic divergence from each other with respect to aggregate effect of 11 characters under study, while much more genetic diversity was observed between the genotypes belonging to different clusters. Since, high or optimum genetic divergence is desired between the parents of hybridization plan for obtaining higher frequency of desirable recombinants, the chances of obtaining good segregants by crossing the little diverse genotypes belonging same cluster are very low. In order to increase the possibility of isolating good segregants in the segregating generations it would be logical to attempt crosses between the diverse genotypes belonging to clusters separated by large inter-cluster distances. In present investigation, vary high inter cluster distances were recorded between cluster II and IV followed by cluster I and IV and cluster $\mathrm{V}$ and II. The lowest inter cluster distance was observed between cluster I and II, followed by cluster III and IV and cluster III and V. Thus, crossing between the genotypes of the above three cluster pairs having very low inter-cluster distances may not be rewarding owing to little genetic diversity among their genotypes.

The intra-cluster group means for eleven characters (Table 3) revealed marked differences between the clusters in respects of cluster means for different characters. The intra-cluster group means for eleven characters revealed marked differences between the clusters in re-
Table 2. Estimates of average intra- and inter-cluster distances in pigeonpea.

\begin{tabular}{lccccc}
\hline Clusters & Cluster 1 & Cluster 2 & Cluster 3 & Cluster 4 & Cluster 5 \\
\hline Cluster 1 & $\mathbf{2 4 4 . 8 1}$ & 299.93 & 558.94 & 690.94 & 524.58 \\
Cluster 2 & & $\mathbf{1 4 9 . 7 0}$ & 535.38 & 727.79 & 689.30 \\
Cluster 3 & & & $\mathbf{2 6 3 . 8 0}$ & 404.74 & 474.86 \\
Cluster 4 & & & & $\mathbf{2 5 3 . 6 2}$ & 533.00 \\
Cluster 5 & & & & & $\mathbf{1 9 1 . 3 9}$ \\
\hline
\end{tabular}

*Bold figures represent intra-cluster distances.

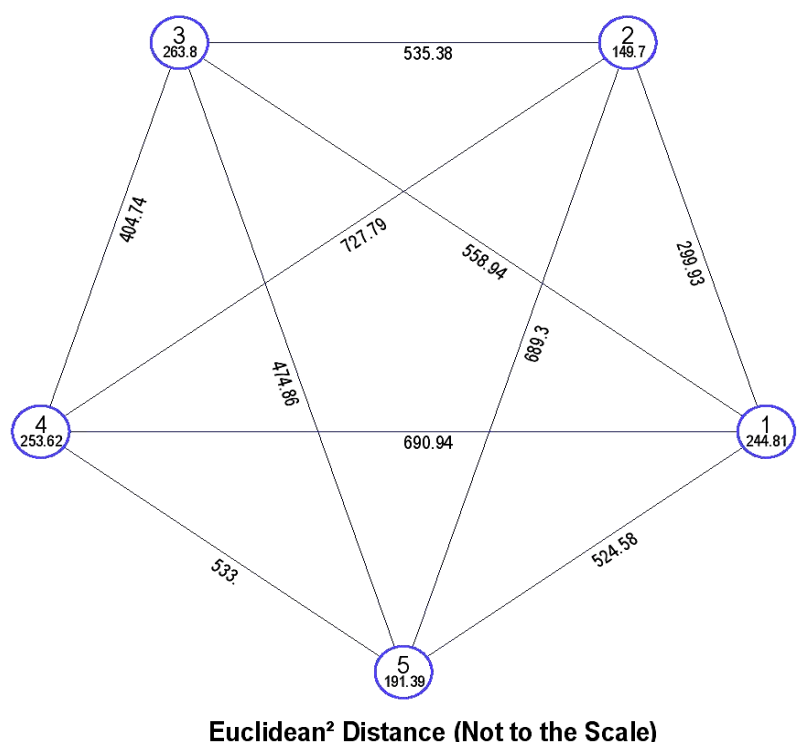

Figure 2. Cluster diagram showing Euclidean ${ }^{2}$ distance.

spects of cluster means for different characters. Cluster I having 4 genotypes, showed highest cluster means for 
100-seed weight, second highest cluster means for seed yield per plant, biological yield per plant and days to maturity besides having lowest mean performance for days to $50 \%$ flowering. Cluster II with four genotypes recorded second highest cluster means for days to maturity, 100-seed weight and harvest index besides having lowest cluster means for secondary branches per plant, pods per plant, seeds per pod and biological yield. Cluster III comprising 8 genotypes, exhibited highest cluster mean for days to maturity and days to $50 \%$ flowering besides having lowest cluster means for plant height, primary branches per plant and seed yield per plant. The three genotypes of cluster IV were responsible for highest cluster mean for plant height, primary branches per plant, secondary branches per plant and seeds per pod while lowest cluster means for 100-seed weight and harvest index. Cluster V possessing four genotypes, has highest means pods per plant, seed yield plant, biological yield per plant and harvest index; second highest cluster means for plant height, primary branches per plant and secondary branches per plant besides having lowest cluster mean for days to maturity. Similar findings were also reported by [4-6].

Further, the efficacy of $\mathrm{D}^{2}$-statistics is improved by its applicability to estimate the relative contribution of the various characters towards genetic divergence [15]. In this context, the highest contribution in manifestation of genetic divergence was exhibited by 100 -seed weight followed by pods per plant, days to maturity, harvest index, biological yield per plant, days to $50 \%$ flowering and seed yield per plant (Table 4).

The above discussion clearly shows wide variation from one cluster to another in respect of cluster means for eleven characters, which indicated that genotypes having distinctly different mean performance for various characters were separated into different clusters. The crossing between the entries belonging to cluster pairs having large inter-cluster distance and possessing high cluster means for one or other characters to be improved may be recommended for isolating desirable recombinants in the segregating generations in pigeonpea. Considering the mean performance for different characters of genotypes belonging to diverse clusters, the promising genotypes for exploitation as parents in hybridization programme were NDA 2, NDA 7-11, IPA 208 and NDA 5-14 of cluster I; NDA 3-3, NDA 98-6, Amar and NDACMS 1-3A of cluster II; NDACMS 1-4A, NDACMS1-6A and ICP 870 of cluster IV and NDA 96-6, ICP 2155, NDA 8-6 and NDAGC 1010 of cluster V. These genotypes may be recommended for crossing with the genotypes of the clusters showing high inter cluster

Table 3. Clusters means for 11 quantitative characters in pigeonpea.

\begin{tabular}{|c|c|c|c|c|c|c|c|c|c|c|c|}
\hline Clusters & $\begin{array}{c}\text { Days to } \\
50 \% \\
\text { flowering }\end{array}$ & $\begin{array}{l}\text { Days to } \\
\text { maturity }\end{array}$ & $\begin{array}{l}\text { Plant } \\
\text { height } \\
(\mathrm{cm})\end{array}$ & $\begin{array}{c}\text { Primary } \\
\text { branches/plant }\end{array}$ & $\begin{array}{c}\text { Secondary } \\
\text { branches/plant }\end{array}$ & Pods/plant & Seeds/pod & $\begin{array}{l}\text { 100-Seed } \\
\text { Wt. (g) }\end{array}$ & $\begin{array}{c}\text { Seed } \\
\text { yield/plant } \\
\text { (g) }\end{array}$ & $\begin{array}{c}\text { Biological } \\
\text { yield/plant (g) }\end{array}$ & $\begin{array}{c}\text { Harvest } \\
\text { index (\%) }\end{array}$ \\
\hline 1 Cluster & 139.25 & 250.5 & 172.84 & 5.15 & 22.32 & 169.32 & 3.38 & 13.02 & 68.09 & 235.11 & 29.04 \\
\hline 2 Cluster & 143.5 & 250.5 & 176.85 & 5.06 & 16.36 & 163.66 & 2.89 & 12.83 & 52.83 & 180.43 & 29.31 \\
\hline 3 Cluster & 145.42 & 252.75 & 172.59 & 5 & 18.98 & 176.22 & 3.34 & 9.58 & 51.35 & 181.13 & 28.29 \\
\hline 4 Cluster & 144.22 & 249.89 & 198.33 & 5.91 & 30.53 & 184.06 & 3.53 & 9.41 & 58.91 & 226.16 & 25.79 \\
\hline 5 Cluster & 142.5 & 249.33 & 179.01 & 5.43 & 23.14 & 234.47 & 3.18 & 10.93 & 73.76 & 240.21 & 30.77 \\
\hline
\end{tabular}

Table 4. Per cent contribution of characters towards genetic diversity.

\begin{tabular}{ccc}
\hline Source & Times Ranked 1 ${ }^{\text {st }}$ & Contribution \% \\
\hline Days to 50\% flowering & 16 & 6.32 \\
Days to maturity & 25 & 9.88 \\
Plant height (cm) & 9 & 3.56 \\
Primary branches/plant & 0 & 0.00 \\
Secondary branches/plant & 1 & 0.40 \\
Pods/plant & 48 & 18.97 \\
Seeds/pod & 1 & 0.40 \\
100-Seed Wt. (g) & 100 & 39.53 \\
Seed yield/plant (g) & 14 & 5.53 \\
Biological yield/plant (g) & 18 & 7.11 \\
Harvest index (\%) & 21 & 8.30 \\
\hline
\end{tabular}


distances mentioned above for isolating transgressive segregants. However, caution should be exercised in selecting very diverse genotypes, because the frequency of heterotic crosses and magnitude of heterosis for yield and its components were found to be higher in crosses between parents with intermediate divergence than the extreme ones.

\section{REFERENCES}

[1] C. Darwin, "The Origin of Species by Means of Natural Selection or the Preservation of Favoured Races in the Struggle for Life,” Philosophical Library, New York, 1859.

[2] R. N. Moll, W. S. Sathawana and H. F. Robinson, "Heterosis and Genetic Diversity in Varietal Crosses of Maize,” Crop Science, Vol. 2, No. 3, 1962, pp. 197-198. http://dx.doi.org/10.2135/cropsci1962.0011183X0002000 30005x

[3] V. Arunachalam, "Genetic Distance in Plant Breeding," Indian Journal of Genetics and Plant Breeding, Vol. 41, No. 2, 1981, pp. 226-236.

[4] M. N. Sawant, A. H. Sonone and S. A. Anarase, "Character Association, Path Coefficient Analysis and Genetic Diversity in Pigeonpea," Journal of Maharashtra Agricultural Universities, Vol. 34, No. 2, 2009, pp. 134-137.

[5] D. Bhadru, "Genetic Studies in Pigeonpea [Cajanus cajan (L.) Millsp],” Electronic Journal of Plant Breeding, Vol. 1, No. 2, 2011, pp. 132-134.

[6] N. Pratap, R. Kumar, S. N. Singh, R. J. Singh and H. R. Verma,"Genetic Divergence in Pigeonpea Collections," Agricultural and Biological Research, Vol. 27, No. 1, 2011, pp. 14-19.

[7] B. R. Murty and V. Arunachalam, "The Nature of Genetic
Divergence in Relation to Breeding System in Crop Plants," Indian Journal of Genetics and Plant Breeding, Vol. 26, No. A, 1966, pp. 188-198.

[8] G. M. Bhatt, "Multivariate Analysis Approach to Selection of Parents for Hybridization Aiming at Yield Improvement in Self Pollinated Crops,” Australian Journal of Agricultural Research, Vol. 21, No. 1, 1970, pp. 1-7. http://dx.doi.org/10.1071/AR9700001

[9] V. G. Panse and P. V. Shukhatme, "Statistical Methods for Agricultural Workers," 2nd Edition, ICAR, New Delhi, 1967, pp. 152-157.

[10] P. C. Mahalanobis, "On the Generalized Distance in Statistics," Proceedings of National Institute of Sciences (India), Vol. 2, No. 1, 1936, pp. 49-55.

[11] C. R. Rao, "Advanced Statistical Methods in Biometric Research,” John Wiley and Sons, New York, 1952.

[12] P. K. Katiyar, R. P. Dua, I. P. Singh, B. B. Singh and F. Singh, "Multivariate Analysis for Genetic Diversity in Early Pigeonpea Accessions," Legume Research, Vol. 27, No. 3, 2004, pp. 164-170.

[13] S. K. Gupta, J. S. Sandhu, S. Singh and R. P. Dua, “Assessment of Genetic Diversity in Pigeonpea [Cajanus cajan (L.) Millsp.],” Crop Improvement, Vol. 35, No. 2, 2008, pp. 142-145.

[14] Y. K. Nag and R. N. Sharma, "Genetic Diversity and Path Coefficient Analysis in Pigeonpea [Cajanus cajan (L.) Millsp.] Germplasm Accessions of Bastar Origin,” Electronic Journal of Plant Breeding, Vol. 3, No. 2, 2012, pp. 818-824.

[15] R. N. De, J. N. Reddy, A. V. S. Rao and K. K. Mohanty, "Genetic Divergence in Early Rice under Two Situation," Indian Journal of Genetics and Plant Breeding, Vol. 52, No. 3, 1992, pp. 225-229. 